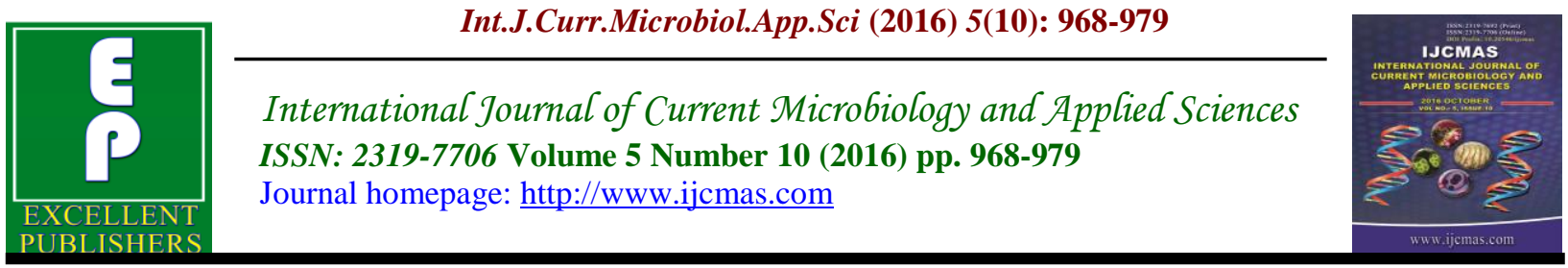

Original Research Article

http://dx.doi.org/10.20546/ijcmas.2016.510.103

\title{
A Study of Arbuscular Mycorrhiza (AM) Root Colonization in the Herbaceous Vegetation of Different Age Series Sponge Iron Solid Waste Dumps
}

\author{
B. Kullu ${ }^{1}$ and N. Behera ${ }^{2}$ \\ ${ }^{1}$ Department of Botany, Utkal University, Odisha, India \\ ${ }^{2}$ Department of Environmental Science, Sambalpur University, Odisha, India \\ *Corresponding author
}

Keywords

Arbuscular mycorrhiza, root colonization, sponge iron solid waste, reclamation.

\section{Article Info}

Accepted:

28 September 2016

Available Online:

10 October 2016

\section{A B S T R A C T}

Mycorrhiza is one of the most important groups of microorganisms which can effectively support the vegetation development in distress habitat like sponge iron solid waste dump. Arbuscular Mycorrhiza (AM) root colonization in the herbaceous vegetation of different age series sponge iron solid waste dumps were assessed. Among the grasses all the species were associated with AM in all the waste dumps and such observation highlights the effective role of grasses as pioneer species during vegetation succession. The percentage of mycorrhizal colonization in the herbaceous plant species decreased with increasing age of the waste dumps and as age of the waste dumps increased, the percentage of plants with very high level decreased in all the dumps. Highest percentage of mycorrhizal root colonization was observed in Eragrostis tenella which was dominant species of the waste dumps. More numbers of plants were with hyphae \& arbuscules $(\mathrm{H}+\mathrm{A})$ structure than hyphae \& vesicle $(\mathrm{H}+\mathrm{V})$ in the waste dumps reflects the importance of synergistic action of hyphae and arbuscule for transfer of nutrients from low nutrient content substrate rather than the development of storage structure like vesicle. Form the study it was concluded that establishment of mycorrhizal association is quite essential for proper vegetational development and subsequent reclamation of the sponge solid waste dumps.

\section{Introduction}

Steel is a vital component of any country's economy and is considered amongst the driving force of modernization. Sponge iron or direct reduced iron (DRI) is mostly used for steel making through secondary sector. India has emerged as the world's largest producer of sponge iron, accounting for $33 \%$ of the global production and the coal based sponge iron production contributes about $80 \%$ of the total capacity of the country
(IBM, 2013). From the coal based sponge iron industry huge amount of solid waste is generated in form of char, dust, accretion material and fly ash (CPCB, 2007). Majority of these solid wastes are dumped on land which creates large areas of black calcareous derelict land (Roy et al., 2002). In developing country like India, reclamation of derelict land is an urgent necessity and one of the effective strategies for the 
reclamation is through revegetation (Singh et al., 2002). However, revegetation of the sponge iron industry solid waste dump is a difficult task looking in to the hostile pedosphereic environment (Pandey and Maiti, 2008). The vegetation development on sponge iron solid waste dump is required for stabilization of the dump, which can be achieved through restoration of soil microorganisms (Mukhopadhyay and Maiti, 2009). One of the most important groups of microorganisms which can effectively support the vegetation development in such scenario is mycorrhiza.

Mycorrhiza is the symbiotic association between soil fungi with the roots of vascular plants (Sieverding, 1991). In mycorrhizal association, the host plant receives mineral nutrients while the fungus obtains photosynthetically derived carbon compounds (Harley, 1989). Arbuscular mycorrhiza (AM) fungi (formerly VAM) are a type of mycorrhiza characterized by forming arbuscules, hyphae and vesicles within root cortex cells (Brundrett, 1991). About $80 \%$ of all terrestrial plant species (Smith and Read, 1997) and 95\% of vascular plants are characteristically mycorrhizal (Quilambo, 2000). AM are among the most common soil microorganisms and constitute an important functional component of the soil-plant system occurring in almost all habitats and climates (Barea et al. 1997), including disturbed soil (Bundrett et al., 1996; McGonigle and Miller, 1996)

It has been well establish that AM fungi improves plant growth in terms of better nutrient uptake, specially phosphorous, water relations, stress tolerance, production of growth promoting substances and protection from root pathogen etc. (Allen and Allen, 1980; Hayman, 1982a; Schreiner et al., 1997; Smith and Read, 1997; Turk et al., 2006). They also have important role in ecosystem establishment (Quoreshi, 2008). The importance of AM for reclamation and reestablishment of vegetation on degraded sites have been emphasized by many workers (Rao \& Tak, 2002; Singh, 2003; Sheoran et al., 2010; Kumar et al., 2010). However reports on AM root association of the plants growing on sponge iron solid waste dumps are scanty in India, where large numbers of sponge iron industries are operating. Therefore in the present study attempt is been made to analyze the AM root colonization in the herbaceous vegetation of different age series sponge iron solid waste dumps in the light of reclamation.

\section{Materials and Methods}

\section{Study site}

The study was carried out in solid waste dumping site of Scans Steels limited, Sundargrah, Odisha during 2011-2012. Geographical location of the area is between 20 $11^{\prime}$ North Latitude and 84 ${ }^{\circ} 19^{\prime}$ East Longitude. Altitude of the area is about $213 \mathrm{~m}$ above the mean sea level. The area experiences tropical climate with three distinct seasons i.e. summer, rainy and winter. The mean annual rainfall in the area is $1422 \mathrm{~mm}$ and mean air temperature of the area varies from $10^{\circ} \mathrm{C}$ to $45^{\circ} \mathrm{C}$. The relative humidity fluctuates from minimum of $40 \%$ to maximum of $83 \%$. In the sponge iron solid waste dumping site, accumulation of solid waste over years resulted in formation of different age series of dumps. Dump age is expressed as time since the establishment of dump in the site. For the present study freshly laid dump $\left(\mathrm{D}_{0}\right), 1$ year $\left(\mathrm{D}_{1}\right), 3$ year $\left(D_{3}\right)$ and 5 year $\left(D_{5}\right)$ old dumps were selected. During dumping of the solid waste, when the dump attains sufficient height, soil of the adjacent area is covered over the dump for stabilization. Thus, $\mathrm{D}_{1}, \mathrm{D}_{3}$ and $\mathrm{D}_{5}$ were with soil cover, where as D0 was 
without soil cover. A natural site adjacent to the waste dumping site was been taken as control site $(\mathrm{C})$ for reference.

\section{Sample collection}

The fine roots of herbaceous plant species in different age series sponge iron solid waste dump and control site were collected randomly and mixed together to get a composite sample for each species. The root samples were kept in polythene bags and brought to the laboratory for mycorrhizal study.

\section{Inspection of AM root colonization}

The root samples were washed thoroughly with tap water in order to remove the adhering soil particles and cut in to pieces of approximately $1 \mathrm{~cm}$ length. The root segments were cleared by heating in $10 \%$ $\mathrm{KOH}(\mathrm{w} / \mathrm{v})$ at $90^{\circ} \mathrm{C}$ in water bath for $30 \mathrm{~min}$ (Phillips and Hayman 1970). After heating, the $\mathrm{KOH}$ solution was poured off and the root samples were washed several times in distilled water. Roots were covered with a freshly prepared alkaline $\mathrm{H}_{2} \mathrm{O}_{2}$ solution to bleach for $60 \mathrm{~min}$. Alkaline $\mathrm{H}_{2} \mathrm{O}_{2}$ was prepared by adding $3 \mathrm{ml}$ of $\mathrm{NH}_{4} \mathrm{OH}_{2}$ to $30 \mathrm{ml}$ of $10 \% \mathrm{H}_{2} \mathrm{O}_{2}$ and $567 \mathrm{ml}$ of distilled water. The bleaching solution was discarded and the roots were rinsed with water. The root samples were then acidified by placing them in $2 \% \mathrm{HCl}(\mathrm{v} / \mathrm{v})$ for $5 \mathrm{~min}$. The roots were again rinsed several times with distilled water. The cleared roots were stained with Lactoglycerol Trypan Blue $(0.05 \%)$ stain and incubated for $45 \mathrm{mins}$ at $90^{\circ} \mathrm{C}$. After staining the root samples were washed with water and placed over glass slide for observation under compound microscope. The level of colonization in each root segment was measured by the method of Giovannetti \& Mosse (1980) which involved gentle squashing of stained root segment on a microscope slide after covering with a cover slip. For each plant species 50 root pieces were observed. The percentage of mycorrhizal colonization was estimated by following formula:

$$
\begin{aligned}
& \text { No. of root colonized with AM } \\
& \text { Mycorrhizal colonization }(\%)=\frac{\text { Total no. of roots inspected }}{\text { N }}=100
\end{aligned}
$$

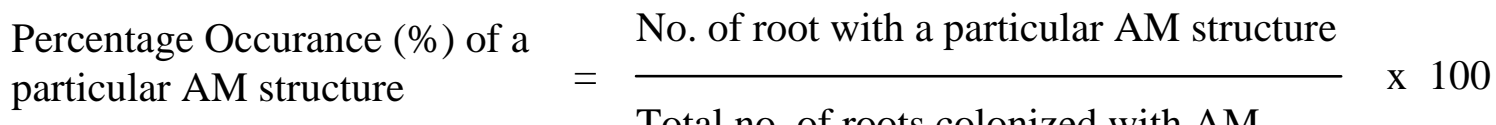

\section{Results and Discussion}

The percentages of mycorrhizal root colonization in herbaceous vegetation (grass, sedge and forbs) of different sites were presented in Appendix-1. Freshly laid dump $\left(\mathrm{D}_{0}\right)$ was devoid of any vegetation, hence there was no scope for studying the mycorrhizal root colonization. Total of 34 herbaceous species in $\mathrm{D}_{1}, 63$ in $\mathrm{D}_{3}$ and 85 in $\mathrm{D}_{5}$ and control site each, were assessed for the study of AM root colonization. It was found that in $\mathrm{D}_{1} 88 \%$ and in $\mathrm{D}_{3}, \mathrm{D}_{5}$ \& Control site each $92 \%$ of the herbaceous plant species were associated with mycorrhiza (Figure 1). Furthere, herbaceous vegetation was divided in three catagories such as: Grass, Sedge and Forbs. In all the sites all the grass species $(100 \%)$ were associated with mycorrhiza. Mycorrhizal association in among the sedges in $\mathrm{D}_{1}$ and $\mathrm{D}_{3}$ were $20 \%$ and $17 \%$ respectively, where 
as in $\mathrm{D}_{5}$ and control site were $14 \%$ each. With respect to forbs, the mycorrhizal association was $100 \%$ in $\mathrm{D}_{1}$ and $\mathrm{D}_{3}$ sites. However, in $\mathrm{D}_{5} \&$ control site, the association was $98 \%$. The percentage of mycorrhizal colonization varies from $0-90 \%$ in different herbaceous plant species of $\mathrm{D}_{1}$, $\mathrm{D}_{3}, \mathrm{D}_{5}$ and Control site (Appendix-1).

Among the grasses, all were found to be associated with mycorrhiza in all the sites. Highest percentage of mycorrhizal root colonization was observed in Eragrostis tenella and lowest in Bothricholoa pertusa in all the sites. Among the sedges (Cyperaceae) only one species Cyperus kyllingia was associated with mycorrhiza in all the sites. Among the forbs, except Celosia agerantea (Amaranthaceae), all were associated with mycorrhiza and highest percentage of mycorrhizal root colonization was observed to be present in Desmodium triflorum in all the sites, whereas lowest percentage of association was in Solanum surattense in $\mathrm{D}_{1}$ and in Gomphrena celsiodes in $\mathrm{D}_{3}, \mathrm{D}_{5}$ and control site. Among all the herbaceous species highest percentage of mycorrhizal root colonization was found in Desmodium triflorum (forbs) and lowest in Cyperus kyllingia (sedge). In general, the percentage of mycorrhizal colonization in the herbaceous plant species decreased with increasing age of the waste dumps.

On the basis of percentage of mycorrhizal root colonization, mycorrhizal association was divided into five levels such as: very high $(\geq 70 \%)$, high $(50-69 \%)$, moderate (20$49 \%)$, low (< 20\%) and no association. Further, mycorrhizal association was categorized into 4 types on the basis of presence AM hyphae $(\mathrm{H})$, arbuscules (A) and vesicle $(\mathrm{V})$ such as: presence of hyphae only $(\mathrm{H})$, hyphae \& arbuscules $(\mathrm{H}+\mathrm{A})$, hyphae \& vesicle $(\mathrm{H}+\mathrm{V})$ and hyphae, arbuscules \& vesicle $(\mathrm{H}+\mathrm{A}+\mathrm{V})$. The number of plant species fall under different level and category of association was represented in Table 1.

With respect to different level of association it was observed that, in $\mathrm{D}_{1} 50 \%$ of the plant species were with very high level, $29 \%$ with high level, $9 \%$ with moderate and $12 \%$ with no association. Plants with low level of association were absent in $\mathrm{D}_{1}$. In $\mathrm{D}_{3} 16 \%$ of the plants were with very high level, $36 \%$ with high level, $6 \%$ with moderate and $5 \%$ with no association. In $\mathrm{D}_{3}$ none of the plants were with low level of association. In $\mathrm{D}_{5} 8 \%$ of the plants were having very high level of association, $60 \%$ were having high level, $22 \%$ were having moderate level, $1 \%$ was having low level and $8 \%$ were having no mycorrhizal association. In control site none of the plants were with very high level of association. However, $32 \%$ of the plants were with high level, $56 \%$ with moderate level, $4 \%$ with low level and $8 \%$ with no association.

In the present study highest percentages of plants were with hyphae, arbuscules and vesicle $(\mathrm{H}+\mathrm{A}+\mathrm{V})$ structure in all the sites. In the waste dumps more percentage (30-19\%) of plants were with hyphae \& arbuscules $(\mathrm{H}+\mathrm{A})$ structure and than percentage (13$10 \%)$ of plants with hyphae \& vesicle $(\mathrm{H}+\mathrm{V})$, where as in the control site more percentage $(35 \%)$ of plants were with hyphae \& vesicle $(\mathrm{H}+\mathrm{V})$ than hyphae \& arbuscules $(\mathrm{H}+\mathrm{A})$ structure $(9 \%)$.

In the younger dumps i.e in $\mathrm{D}_{1}$ and $\mathrm{D}_{3}$ equal percentage (i.e $10 \& 12 \%$ ) of the plants were hyphae \& arbuscules $(\mathrm{H}+\mathrm{A})$ and hyphae only $(\mathrm{H})$ respectively, but in older dump i.e in $\mathrm{D}_{5}$, more percentage $(13 \%)$ of plants were with hyphae \& vesicle $(\mathrm{H}+\mathrm{V})$ than $(10 \%)$ hyphae only $(\mathrm{H})$. There was a gradual increasing trend in the percentage of plants 
with hyphae \& vesicle $(\mathrm{H}+\mathrm{V})$ structures with increasing age of the waste dumps. However, no specific trend was observed with respect to the percentage of plants associated with hyphae, arbuscules and vesicle $(\mathrm{H}+\mathrm{A}+\mathrm{V})$, hyphae \& arbuscules $(\mathrm{H}+\mathrm{A})$ and hyphae $(\mathrm{H})$ only with age of the waste dumps. In the control site about equal percentage of the plant were associated with hyphae, arbuscule \& vesicle $(\mathrm{H}+\mathrm{A}+\mathrm{V})$ and with hyphae \& vesicle $(\mathrm{H}+\mathrm{V})$ structures.

In the present study it was observed that relatively high percentage of herbaceous plant species have AM colonization in their root. This reflects the effective role of AM association in plants colonizing the sponge iron solid waste dumps. The importance of mycorrhizal association for vegetation establishment in coal mine spoil (Kumar et al., 2003; Ekka \& Behera, 2010), lime stone mine spoil (Singh and Jamaluddin, 2011), toxic mine tailings (Leung et al., 2007), sand dunes (Beena et al., 2001) and salt alkaline soil (Raghuwanshi and Upadhyay, 2010) are already being emphasized, which are in agreement with the observation of present study.

Among the grasses, all were found to be associated with mycorrhiza in all waste dumps which highlights the effective role of grasses as pioneer species during vegetation succession in different derelict lands (Singh, 2004; Singh and Singh, 2006; Bohre et al., 2012). The absence of mycorrhizal root colonization in some of the plant species could be explained by the fact that families such as Chenopodiaceae, Fumariaceae, Zygophylaceae, Cactaceae, Junceaceae, Cyperaceae, Amaranthaceae and Commelinaceae are widely thought to be non mycorrhizal, although some of the species belonging to these families on occasion to be associated with AM under certain condition (Newman and Reddell,
1987; Neeraj et al., 1991 and Oringa et al., 1997). The absence of AM association in the non-mycorrhizal plant species is might be due to the presence of antifungal compounds in the root cortical issue or in root exudates (Tester et al., 1987; Thangaswamy et al., 2005). Highest percentage of mycorrhizal root colonization in Eragrostis tenella among the grasses and in Desmodium triflorum among forbs enables them to adapt themselves better than the other species in the waste dumps and to become dominant grass and forbs respectively (Kullu and Behera, 2011).

The present study revealed that with respect to the level AM root colonization, as the age of the waste dumps increased the percentage of plants with very high level of association gradually decreased. In the control site plants with very high level of association were absent and relatively high percentage of plants were with moderate level of association were present. Further, in $\mathrm{D}_{1}$ and $\mathrm{D}_{3}$ plants with low level of association were not present. All these observations indicated that at very early stage of vegetation succession, very high level of AM association of outmost importance for the establishment herbaceous species and as the succession precedes the level of association gradually decrease. This is supported by the findings of Ekka \& Behera (2010) in different age series coal mine spoil.

Presence of any one among the three types of AM structures hyphae, arbuscule and vesicle are normally used to designate the AM association (Pezzani et al., 2006). Arbuscules are ephemeral structures which are present in active root and responsible for nutrient transfer to the host plant (Cox and Tinker, 1976). AM vesicles are considered as storage organ produced in the older region of the infection (Kumar et al., 2003). 
Table.1 Number of plant species with different level and category of AM root colonization in different age series sponge iron solid waste dumps (D0, D1, D3 and D5) and control site (C).

\begin{tabular}{|c|c|c|c|c|c|}
\hline \multicolumn{2}{|c|}{ Categorization } & \multicolumn{4}{|c|}{ Percentage of plants in different sites } \\
\hline & & $\mathrm{D}_{1}$ & $\mathrm{D}_{3}$ & $\mathrm{D}_{5}$ & $\mathrm{C}$ \\
\hline \multirow{5}{*}{ 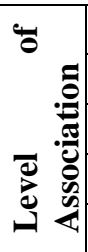 } & Very high $(\geq 70 \%)$ & 50 & 25 & 8 & 0 \\
\hline & High (50-69\%) & 29 & 57 & 60 & 32 \\
\hline & Moderate (20-49\%) & 09 & 10 & 22 & 56 \\
\hline & Low $(<20 \%)$ & 0 & 0 & 2 & 4 \\
\hline & No association & 12 & 8 & 8 & 8 \\
\hline \multirow{4}{*}{ 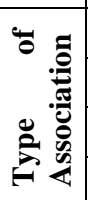 } & $\mathbf{H}$ & 10 & 12 & 10 & 20 \\
\hline & $\mathbf{H}+\mathbf{A}$ & 30 & 16 & 19 & 9 \\
\hline & $\mathbf{H + V}$ & 10 & 12 & 13 & 35 \\
\hline & $\mathbf{H}+\mathbf{A}+\mathbf{V}$ & 50 & 60 & 58 & 36 \\
\hline
\end{tabular}

* Type of AM association: hyphae only $(\mathrm{H})$; hyphae \& arbuscules $(\mathrm{H}+\mathrm{A})$; hyphae \& vesicle $(\mathrm{H}+\mathrm{V})$; hyphae, arbuscules \& vesicle $(\mathrm{H}+\mathrm{A}+\mathrm{V})$

Fig.1 Percentage of plant species associated with AM in different age series sponge iron solid waste dumps (D0, D1, D3 and D5) and control site (C).

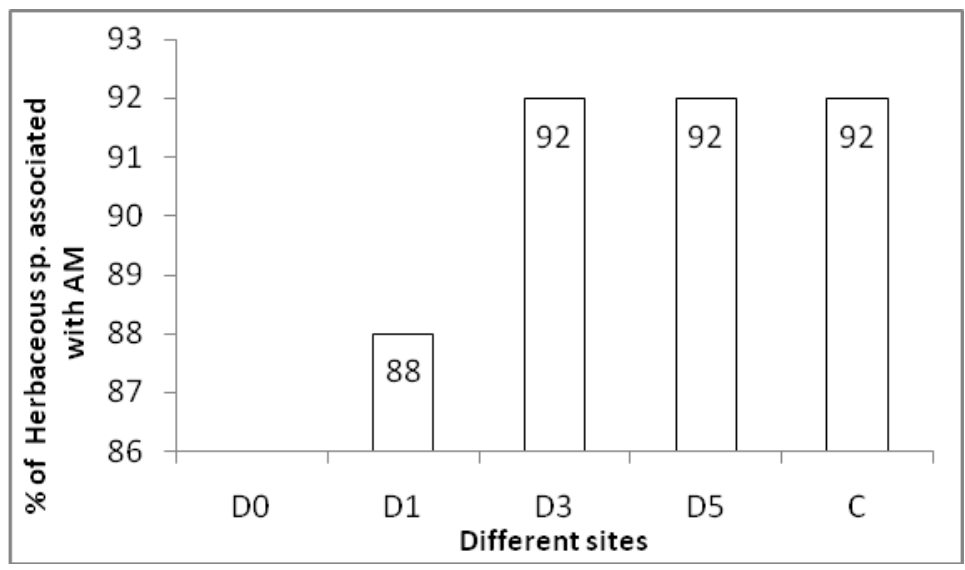

Highest percentage of plants with hyphae, arbuscule and vesicle vesicle $(\mathrm{H}+\mathrm{A}+\mathrm{V})$ structures in all the sites indicated the importance of AM structure for nutrient transfer as well as for storage organ. More percentage of plants were with hyphae \& arbuscules $(\mathrm{H}+\mathrm{A})$ structure than hyphae \& vesicle $(\mathrm{H}+\mathrm{V})$ in the waste dumps reflects the importance of synergistic action of hyphae and arbuscule for transfer of nutrients from low nutrient content substrate rather than the development of storage structure like vesicle, during the early stage of vegetation succession as observed in the present study. Gradual increasing trend in the percentage of plants associated with hyphae \& vesicle $(\mathrm{H}+\mathrm{V})$ structures with increasing age of the waste dumps, might be explained by the fact that with increasing age, there is gradual nutrient enrichment in the waste dumps which might reduce the necessity of nutrient absorptive structure and storage structure vesicle develops more in number. About equal percentage of the plant associated were with hyphae, arbuscule \& vesicle $(\mathrm{H}+\mathrm{A}+\mathrm{V})$ and with hyphae \& vesicle $(\mathrm{H}+\mathrm{V})$ in the control site indicate the importance of storage structure like 
vesicle in stable herbaceous plant community.

In conclusion, from the present study it was found that relatively high percentage of herbaceous plant species have AM colonization in their root. This reflects the effective role of AM association in plants colonizing the sponge iron solid waste dumps. AM association is well known to enhance plant growth by increasing nutrient uptake and stress tolerance. Solid wastes generated from iron industrial units are usually deficient in nutrients and have high metal contents, low hydrological regime and high $\mathrm{pH}$. Thus, the establishment of mycorrhizal association is quite essential for proper vegetational development and subsequent reclamation of the solid waste dumps. In this connection knowledge of the AM fungi associated with the plants growing on sponge iron solid waste dump has crucial importance for their use in future reclamation and management programs.

\section{References}

Allen, E.B. and Allen, M.T. 1980. Natural re-establishment of vesicular arbuscular mycorrhizae following strip-mine reclamation in Wyoming. $J$. Appl. Ecol., 17: 139-147.

Barea, J.M., Azcon-Aguilar, C. and Azcon, R. 1997. Interaction between mycorrhizal fungi and rhizosphere microorganisms with the context of sustainable soil-plant system. In: A.C. Gange and V.K. Brown (eds.) Multitrophic interactions in terrestrial systems, pp. 65-77.

Beena, K.R., Arun, A.B., Raviraja, N.S. and Sridhar, K.R. 2001. Association of arbuscular mycorrhizal fungi with plants of coastal sand dunes of west coast of India. Trop. Ecol., 42(2): 213222.
Bohre, P., Chaubey, O.P. and Singhal, P.K. 2012. Bio-restoration and its impact on species diversity and biomass accumulation of ground flora community of degraded ecosystem of coalmines. Int. J. Bio-Sci. BioTechnol., 4(4): 63-79.

Brundrett, M.C. 1991. Mycorrhizas in natural ecosystems. In: Macfayden A, Begon M, Fitter A. H. (Eds.) Advances in Ecological Research, London: Academic press, 21: 171-313.

Brundrett, M., N. Bougher, B. Dell, T. Grove and N. Malajczuk. 1996. Working with mycorrhizas in forestry and agriculture. ACIAR (Austral. Cen. Int. Agric. Res.) Monograph, pp: 32.

Cox, G. and Tinker, P.B. 1976. Translocation and transfer of nutrients in vesicular-arbuscular mycorrhizas. The arbuscules and phosphorous transfer: A qualitative ultrastructure study. New Phytologist, 77: 371-378.

CPCB. 2007. Sponge Iron Industry. Comprehensive industry document series. Central Pollution Control Board (Ministry of Environment and Forests, Govt. of India). COINDS/66/2006-07. pp: 87-98.

Ekka, N.J. and Behera, N. 2010. A study of the mycorrhizal association with vegetation on coal mines spoil. The Bioscan, 5(3): 369-372.

Giovannetti, M. and Mosse, B. 1980. An evaluation of techniques for measuring vesicular arbuscular mycorrhizal infection in roots. New Phytol., 84: 489-500.

Harley, J.L. 1989. The significance of mycorrhiza. Mycol. Res., 92: 129-139.

Hayman, D.S. 1982a. Endomycorrhizae in interactions between nonpathogen soil microorganisms and plants. Elseveir. Amsterdam. pp. 401- 442

IBM. 2013. Iron \& Steel and Scrap. Indian mineral year book (Part- II: Metals \& 
Alloys), $51^{\text {st }}$ edition. Indian Bureau of Mines, Ministry of Mines (IBM), Government of India, pp.1-26.

Kullu, B. and Behera, N. 2011. Vegetational succession on different age series sponge iron solid waste dumps with respect to top soil application. Res. J. Environ. Earth Sci., 3(1): 38-45.

Kumar, A., Mangla, C., Aggarwal, A. and Parkash, V. 2010. Arbuscular mycorrhizal fungal dynamics in the rhizospheric soil of five medicinal plant species. Middle-East J. Scientific Res., 6: 281-288.

Kumar, A., Raghuwanshi, R. and Upadhyay, R.S. 2003. Vesicular-arbuscular mycorrhizal association in naturally revegetated coal mine spoil. Trop. Ecol., 44(2): 253-256.

Leung, H.M., Ye, Z.H. and Wong, M.H. 2007. Survival strategies of plants associated with arbuscular mycorrhizal fungi on toxic mine tailings. Chemosphere, 66: 905-915.

McGonigle, T.P. and Miller, M.H. 1996. Development of fungi below ground in association with plants growing in disturbed and undisturbed soils. Soil Biol. Biochem., 28: 263-269.

Mukhopadhyay, S. and Maiti, S.K. 2009. Biofertiliser: VAM fungi- Future prospect for biological reclamation of mine degreaded lands. Indian $J$. Environ. Protection, 29(9): 801-808.

Neeraj, Shankar, A., Mathew, J. and Varma A. K. 1991. Occurrence of VA mycorrhizae within Indian semi-arid soild. Biol. Fertility of Soils, 11:140144.

Newman, E.I. and Reddell, P. 1987. The distribution of mycorrhizas among families of vascular plants. New Phytol., 106: 745-751.

Oringa, W.A., vanAndel, J.A. and McDonnell, A.M.P. 1997. Nutritional soil heterogeneity and mycorrhiza as determinants of plant species diversity. Acta Botanica Neerlandica, 46: 237254.

Pandey, S. and Maiti, T. 2008. Physicochemical and Biological characterization of slag disposal site at Burnpur, West Bengal. Poll. Res., 27(2):345-348.

Pezzani, F., Montana, C. and Guevara, R. 2006. Associations between arbuscular mycorrhizal fungi and geasses in the successional context of a two-phase mosaic in the Chihuahuan Desert. Mycorrhiza, 16: 285 - 295.

Phillips, J.M. and Hayman, D.S. 1970. Improved procedures for clearing roots and staining parasitic and vesiculararbuscular mycorrhizal fungi for rapid assessment of infection. Trans Britain Mycol. Soc., 55: 158161.

Quilambo, O.A. 2000. Functioning of peanut (Arachis hypogaea L.) under nutrient deficiency and drought stress in relation to symbiotic associations.PhD thesis. University of Groningen, the Netherlands. Van Denderen B.V., Groningen. ISBN 903671284X.

Quoreshi, A.M. 2008. The use of mycorrhizal biotechnology in restoration of disturbed ecosystem. In: Siddiqui Z. A. et al (eds) Mycorrizae: sustainable agriculture and forestry. Springer Science + Business media B.V., pp 303-320.

Raghuwanshi, R. and Upadhyay, R.S. 2010. Status of mycorrhizal fungi in a salinealkaline habitat. Biological Forum An Int. J., 2(1): 60-62.

Rao, A.V. and Tak, R. 2002. Growth of different tree species and their nutrient uptake in limestone mine spoil as influenced by arbuscular mycorrhizal (AM)-fungi in Indian arid zone. $J$. Arid Environ., 51(1): 113-119. 
Roy, A., Basu, S.K. and Singh, K.P. 2002. Modeling ecosystem development on blast furnace slag dumps in a tropical region. Simulation, 78(9): 531-542.

Schreiner, R.P., Mihara, K.L., McDaniel, H. and Bethlenfalvay, G.J. 1997. Mycorrhizal functioning influence plant and soil functions and interactions. Plant Soil, 188: 199-209.

Sheoran, V., Sheoran, A.S. and Poonia, P. 2010. Soil reclamation of abandoned mine land by revegetation: A review. Int. J. Soil, Sediment and Water, 3(2): Article 13, pp. 1-20.

Sieverding, E. 1991. Vesicular-Arbuscular Mycorrhizal Management in Tropical Ecosystems. Deutche Gesllshaft für TEchnische Zusammnearbeit (GTZ) GmbH Press. Germany. 371 p.

Singh, A. 2004. Herbaceous biomass yield on an age series of naturally revegetated mine spoils in a dry tropical environment. J. Indian Institute of Sci., 84: 53-56.

Singh, A.K. and Jamaluddin. 2011. Status and diversity of arbuscular mycorrhizal fungi and its role in natural regeneration on limestone mined spoils. Biodiversitas, 12(2): 107-111.
Singh, A.N. and Singh, J.S. 2006. Experiments on ecological restoration of coal mine spoil using native trees in a dry tropical environment, India: a synthesis. New Forest, 31: 25-39.

Singh, A.N., Raghubanshi, A.S. and Singh, J.S. 2002. Plantations as a tool for mine spoil restoration. Curr. Sci., 82: 1436-1441.

Singh, S. 2003. Role of mycorrhiza in reclamation of mine spoils, Mycorrhiza News, 15(3), pp. 2-9.

Smith, S.E. and Read, D.J. 1997. Mycorrhizal Symbiosis, 2nd edition, Academic Press. 605pp.

Tester, M., Smith, S.E. and Smith, F.A. 1987. The phenomenon of "nonmycorrhizal" plants. Canadian J. Bot., 65: 419-431.

Thangaswamy, S., Padmanabhan, C., Yu, J.J. and Hoon, K. 2005. Occurrence and quantification of vesiculararbuscular mycorrhizal (VAM) fungi in industrial polluted soils. $J$. Microbiol. Biotechnol., 15: 147-154.

Turk, M.A., T.A. Assaf, K.M. Hameed and Al-Tawaha, A.M. 2006. Significance of Mycorrhizae. World J. Agri. Sci., 2(1): 16-20.

\section{How to cite this article:}

Kullu, B., and Behera, N. 2016. A Study of Arbuscular Mycorrhiza (AM) Root Colonization in the Herbaceous Vegetation of Different Age Series Sponge Iron Solid Waste Dumps. Int.J.Curr.Microbiol.App.Sci. 5(10): 968-979. doi: http://dx.doi.org/10.20546/ijcmas.2016.510.103 
Appendix-1: Percentage of Arbuscular mycorrhizal (AM) root colonization in herbaceous vegetation of different age series sponge iron solid waste dumps $\left(\mathrm{D}_{0}, \mathrm{D}_{1}, \mathrm{D}_{3}\right.$ and $\left.\mathrm{D}_{5}\right)$ and control site $(\mathrm{C})$.

\begin{tabular}{|c|c|c|c|c|c|c|c|}
\hline $\begin{array}{l}\text { Sl } \\
\text { no }\end{array}$ & Name & Family & $\mathbf{D}_{\mathbf{0}}$ & $\mathbf{D}_{1}$ & $\mathbf{D}_{3}$ & $\mathbf{D}_{5}$ & $\mathbf{C}$ \\
\hline & Grass & & & & & & \\
\hline 1 & Alloteropsis cimicina (L.) Stapf. & Poaceae & _ & 68 & 65 & 60 & 55 \\
\hline 2 & Aristidia adscensionis L. & Poaceae & _ & - & - & 56 & 51 \\
\hline 3 & Aristidia hystrix L.f & Poaceae & - & - & 63 & 60 & 54 \\
\hline 4 & Bothricholoa pertusa L. & Poaceae & _ & 48 & 43 & 40 & 35 \\
\hline 5 & Chloris barbata $\mathrm{Sw}$. & Poaceae & - & - & - & 58 & 46 \\
\hline 6 & Cynodon dactylon (L.) Pers. & Poaceae & - & - & 78 & 75 & 60 \\
\hline 7 & $\begin{array}{l}\text { Dactyloctenium aegyptium (L.) P. } \\
\text { Beav. }\end{array}$ & Poaceae & - & 57 & 55 & 50 & 43 \\
\hline 8 & $\begin{array}{l}\text { Dicanthium annulatum (Forssk) } \\
\text { Staff. }\end{array}$ & Poaceae & - & & 58 & 52 & 45 \\
\hline 9 & $\begin{array}{l}\text { Dicanthium aristatum (Poir.) } \\
\text { Hubbard. }\end{array}$ & Poaceae & - & 53 & 50 & 50 & 44 \\
\hline 10 & Digitaria biformis Willd. & Poaceae & - & - & - & 53 & 40 \\
\hline 11 & Digitaria cilliaris (Retz.)Koeler. & Poaceae & - & - & 57 & 54 & 48 \\
\hline 12 & Digitaria longiflora (Retz.) Pers. & Poaceae & - & - & & 46 & 43 \\
\hline 13 & Echinochola colona (L.) Link. & Poaceae & - & - & 61 & 58 & 50 \\
\hline 14 & Eleusine indica (L.) Gaerthn. & Poaceae & - & - & - & 49 & 42 \\
\hline 15 & Eragrostis riparia Willd. & Poaceae & - & 78 & 76 & 73 & 51 \\
\hline 16 & Eragrostis tenella (L.) P.Beav & Poaceae & - & 88 & 85 & 78 & 45 \\
\hline 17 & Eragrostis unioloides Retz. & Poaceae & - & 83 & 78 & 75 & 53 \\
\hline 18 & Hemarthria compressa (L.) R. Br. & Poaceae & - & - & - & 58 & 42 \\
\hline 19 & Iseilema anthephoroides Hack. & Poaceae & - & - & - & 52 & 38 \\
\hline 20 & Leersia hexandra $\mathrm{Sw}$. & Poaceae & - & - & - & 74 & 52 \\
\hline 21 & $\begin{array}{l}\text { Oplismenus burmanii (Retz.) } \\
\text { P.Beauv. }\end{array}$ & Poaceae & - & - & - & 66 & 46 \\
\hline 22 & Panicum notatum Retz. & Poaceae & - & 55 & 53 & 51 & 40 \\
\hline 23 & Panicum psilopodium Trin. & Poaceae & - & - & 50 & 47 & 42 \\
\hline 24 & Panicum repens $\mathrm{L}$. & Poaceae & - & - & - & 58 & 53 \\
\hline 25 & Panicum triferon Schult. & Poaceae & - & - & 56 & 54 & 46 \\
\hline 26 & Paspalidium flavidum Retz. & Poaceae & - & 73 & 70 & 65 & 49 \\
\hline 27 & Paspalum scorbiculatum L. & Poaceae & - & 58 & 55 & 52 & 46 \\
\hline 28 & Saccharum spontaneum L .Mant & Poaceae & - & - & 60 & 58 & 51 \\
\hline 29 & Setaria glauca Retz. & Poaceae & - & 65 & 59 & 52 & 42 \\
\hline 30 & Sporobolus diander Retz. & Poaceae & - & - & 67 & 60 & 53 \\
\hline
\end{tabular}




\begin{tabular}{|c|c|c|c|c|c|c|c|}
\hline & Sedge & & & & & & \\
\hline 31 & Cyperus iria L. & Cyperaceae & - & 0 & 0 & 0 & 0 \\
\hline 32 & Cyperus kyllingia Endl. & Cyperaceae & - & 23 & 21 & 17 & 15 \\
\hline 33 & Cyperus puntitculatus Vahl & Cyperaceae & - & 0 & 0 & 0 & 0 \\
\hline 34 & Cyperus rotundous $\mathrm{L}$. & Cyperaceae & - & 0 & 0 & 0 & 0 \\
\hline 35 & Cyperus tenucispica Steud. & Cyperaceae & - & - & - & 0 & 0 \\
\hline 36 & Fimbristylis bisumbellata Forssk. & Cyperaceae & - & 0 & 0 & 0 & 0 \\
\hline 37 & $\begin{array}{l}\text { Fimbristylis ovata Burm f. } \\
\text { Forbs }\end{array}$ & Cyperaceae & - & - & 0 & 0 & 0 \\
\hline 38 & Achyranthus aspera $\mathrm{L}$. & Amaranthaceae & - & - & 32 & 23 & 18 \\
\hline 39 & Celosia agerantea $\mathrm{L}$. & Amaranthaceae & - & - & - & 0 & 0 \\
\hline 40 & Gomphrena celsiodes (Ait) R.Br & Amaranthaceae & - & - & 26 & 20 & 15 \\
\hline 41 & Ageratum conyzoides L. & Asteraceae & _- & _ & 66 & 58 & 54 \\
\hline 42 & Blumea lasera (Burm.f) D.C & Asteraceae & - & - & 72 & 65 & 60 \\
\hline 43 & Caesulia axillaris Roxb. & Asteraceae & - & _ & 64 & 58 & 53 \\
\hline 44 & Eclipta prostata L. & Asteraceae & - & - & 54 & 50 & 46 \\
\hline 45 & Emilia sonchifolia L.DC & Asteraceae & - & _ & 50 & 46 & 40 \\
\hline 46 & Tridax procumbense $\mathrm{L}$. & Asteraceae & - & 74 & 70 & 65 & 54 \\
\hline 47 & Borreria hispida (L.) K. Schum. & Boraginaceae & - & 70 & 68 & 64 & 48 \\
\hline 48 & Commolina bengalensis $\mathrm{L}$. & Commelinaceae & - & - & - & 46 & 35 \\
\hline 49 & Murdania nudiflora L. & Commelinaceae & - & - & - & 44 & 30 \\
\hline 50 & Toningea axilaris (L.) Kuntze & Commelinaceae & - & - & - & 40 & 28 \\
\hline 51 & Evolvulus alsinoides L. & Convolvulaceae & - & 76 & 73 & 67 & 60 \\
\hline 52 & Evolvulus nummularius L. & Convolvulaceae & - & 78 & 75 & 65 & 58 \\
\hline 53 & Ipomea obscura Ker-Gawl & Convolvulaceae & - & 80 & 76 & 68 & 60 \\
\hline 54 & Merremia tridentata $\mathrm{L}$. & Convolvulaceae & - & - & - & 54 & 50 \\
\hline 55 & Euphorbia hirta L. & Euphorbiaceae & - & 63 & 60 & 57 & 52 \\
\hline 56 & Phyllanthus fraternus Webster & Euphorbiaceae & - & - & 59 & 55 & 41 \\
\hline 57 & Phyllanthus simplex Retz. & Euphorbiaceae & - & - & 55 & 50 & 48 \\
\hline 58 & Phyllanthus urinaria L. & Euphorbiaceae & - & - & 53 & 49 & 40 \\
\hline 59 & Sebastiania chamaelea (L.) Muell. & Euphorbiaceae & - & - & - & 43 & 38 \\
\hline 60 & Aeschynomene indica $\mathrm{L}$. & Fabaceae & - & 68 & 65 & 58 & 51 \\
\hline 61 & Alysicarpus monilifer (L.)DC & Fabaceae & - & 77 & 75 & 68 & 44 \\
\hline 62 & Alysicarpus vaginalis (L.)DC & Fabaceae & - & 74 & 71 & 64 & 43 \\
\hline 63 & Desmodium triflorum (L.)DC & Fabaceae & - & 90 & 88 & 85 & 52 \\
\hline 64 & $\begin{array}{l}\text { Indigofera enneaphylla L. (linnaei } \\
\text { Ali) }\end{array}$ & Fabaceae & - & - & - & 65 & 46 \\
\hline 65 & Medicago sativa $\mathrm{L}$. & Fabaceae & - & - & - & 52 & 41 \\
\hline 66 & Zornia diphylla (L.) Pers. & Fabaceae & - & 73 & 70 & 65 & 53 \\
\hline 67 & Leucas aspera (Willd.) Link. & Lamiaceae & - & 68 & 63 & 56 & 45 \\
\hline 68 & Leucas cephalotus (Roth) Spreng & Lamiaceae & - & _ & 58 & 51 & 40 \\
\hline
\end{tabular}




\begin{tabular}{llclllll}
\hline $\mathbf{6 9}$ & Hyptis suaveolens L. & Lamiaceae & - & - & - & 48 & 36 \\
$\mathbf{7 0}$ & Ammania baccifera L. & Lythraceae & - & - & 62 & 55 & 50 \\
$\mathbf{7 1}$ & Sida acuta Burm f. & Malvaceae & - & - & 68 & 63 & 43 \\
$\mathbf{7 2}$ & Sida rhombifolia L. & Malvaceae & - & - & 65 & 60 & 41 \\
$\mathbf{7 3}$ & Sida cordata Burm f. & Malvaceae & - & - & 60 & 56 & 39 \\
$\mathbf{7 4}$ & Urena sinuota L. & Malvaceae & - & - & 58 & 50 & 43 \\
$\mathbf{7 5}$ & Molluga pentaphylla L. & Molluginceae & - & - & 63 & 56 & 51 \\
$\mathbf{7 6}$ & Ludwigia parviflora Roxb. & Onagraceae & - & - & - & 48 & 38 \\
& (Perennis) & Polygelaceae & - & - & - & 45 & 33 \\
$\mathbf{7 7}$ & Polygela chinesis autt. non. L. & Rubiaceae & - & 83 & 76 & 70 & 44 \\
$\mathbf{7 8}$ & Oldenlandia corymbosa L. & Scrophulariaceae & - & 72 & 69 & 64 & 50 \\
$\mathbf{7 9}$ & Linderina ciliata (Colsm.) & Scrophulariaceae & - & 75 & 70 & 68 & 53 \\
$\mathbf{8 0}$ & Linderina crustaceae (L.) & & & & & & \\
& F.V.Muell. & Scrophulariaceae & - & 58 & 47 & 45 & 40 \\
$\mathbf{8 1}$ & Scoparia dulcis L. & Solanaceae & - & 32 & 30 & 27 & 22 \\
$\mathbf{8 2}$ & Solanum surattense Burm f. & Sterculiaceae & - & 55 & 53 & 46 & 35 \\
$\mathbf{8 3}$ & Melochia chorchorifolia L. & Tiliaceae & - & - & 54 & 51 & 43 \\
$\mathbf{8 4}$ & Chorchorious aestuans L. & Voilaceae & - & - & 53 & 46 & 38 \\
$\mathbf{8 5}$ & Hybanthus enneaspaermus (L.) F.V. & & & & \\
& Muell. & & & & &
\end{tabular}

_, indicates absence of the plant species 